\title{
Research on Task-Based Workbook for Developing English Language Speaking Skills of First Year College EFL Students
}

\author{
Yu Hu \\ School of the English Language and Culture, Xiamen University Tan Kah Kee College, Xiamen, China \\ Email: 348200162@qq.com
}

How to cite this paper: Hu, Y. (2021). Research on Task-Based Workbook for Developing English Language Speaking Skills of First Year College EFL Students. Open Journal of Social Sciences, 9, 339-346. https://doi.org/10.4236/jss.2021.95017

Received: April 6, 2021

Accepted: May 15, 2021

Published: May 18, 2021

Copyright $\odot 2021$ by author(s) and Scientific Research Publishing Inc. This work is licensed under the Creative Commons Attribution International License (CC BY 4.0).

http://creativecommons.org/licenses/by/4.0/

\begin{abstract}
This study was taken with an ardent goal to produce a task-based workbook for developing English language speaking skills of first year college EFL students in China. The existing instructional materials were analyzed in the study which reveals the shortage of them to teach speaking skills for first year college EFL students in Xiamen University Tan Kah Kee College. Based on the need, a task-based workbook was produced, which was modified and improved based on the evaluation of college English teachers and experts. The finalized workbook is ready to be utilized in teaching speaking skills for the first year college EFL students.
\end{abstract}

\section{Keywords}

Task-Based Language Learning (TBLT), Workbook, Speaking Skills, EFL Students

\section{Introduction}

With the development of the global economy, the significant status of English is gradually highlighted all over the world, more so in China, a rapidly developing country. "Good English ensures a bright future" is the motto which parents and teachers always inculcate in their children and students. Even the reputation and enrollment of a school depend on the English education. The number of English language learners keeps growing every year, which leaves the pressure to the government and schools to ensure the effective instructional practices for English language learners and their academic progress.

College English Curriculum Requirements, which has served as the national syllabus for teaching English as a foreign language at the college level in China, shows its dominant pragmatic orientation. It states that the primary objective of 
College English is to develop students' ability to use English in a well-rounded way, especially in listening and speaking, so that in their future studies and careers as well as social interactions they will be able to communicate effectively and properly (The National Foreign Language Teaching Advisory Board, 2020).

Analyzing the syllabus of college English, the researcher found out that speaking class is not included, and the teaching focus is still on listening, reading and writing. The purpose of teaching is to get a good pass rate on the CET examination in which speaking skills are not tested compulsively. As a result of inefficient instruction, most of the graduates' communicative ability is insufficient as what they learned is "mute English" (Huang, 2006).

Considering the previously cited facts, the researcher decided to prepare a task-based workbook for developing English language speaking skills of the first year EFL students in Xiamen University Tan Kah Kee College (TKKC), China. As an English learner for so many years and currently a college English teacher, the researcher strongly feels that something should be done to improve college English teaching in China. Effective instruction should be provided to meet the needs of the students and the demand of the society. In addition to the focus of teaching listening, reading and writing, a coherent and sustained effort to improve the speaking skills of college EFL students is needed.

\section{Theoretical Framework}

Task-Based Language Teaching (TBLT) was beginning to attract attention in 1980s. If official documents are to be believed, TBLT has become a cornerstone of many educational institutions and ministries of education around the world (Nunan, 2004). Task-Based Language Teaching (TBLT) refers to an approach based on the use of tasks as the core unit of planning and instruction in language teaching (Richards \& Rodgers, 2001). TBLT proposes the notion of "task" as a central unit of planning and teaching. Task-based learning sees learning as arising from particular tasks the students do in the classroom and has been seen increasingly as a logical development from communicative language teaching (Cook, 2008).

Richards and Rodgers believe that Language learning depends on immersing students not merely in "comprehensible input" but in tasks that require them to negotiate meaning and engage in naturalistic and meaningful communication. They assert that engaging learners in task work provide a better context for the activation of learning processes than form-focused activities, and, hence, ultimately provides better opportunities for language learning to take place. If learning is doing tasks, teaching means specifying and helping with the tasks (Cook, 2008).

\section{Research Design and Procedure}

\subsection{Research Design}

The descriptive research method was employed in this study. This study gathered information or data about the instructional materials, teaching methods 
in TKKC. The researcher had no control over the variables, which is the main characteristic of the descriptive method (Kothari, 2008). This research is descriptive because it sought to prepare a Workbook for developing English language speaking skills which will be used in English language teaching. It includes the preparation and evaluation of the Workbook based on the principles of TBLT. Eventually, the said Workbook will be utilized to improve teachers' instruction and enhance EFL students' speaking skills in TKKC.

The respondents of this study were 54 EFL students, 15 college English teachers and 3 experts in TKKC who were selected on a random basis. These respondents gave their responses to the questionnaires constructed by the researcher.

\subsection{Research Instruments}

The researcher utilized three types of research instruments, namely:

1) The Questionnaire

Initially, questionnaires were provided to collect the information on existing instructional materials.

Secondly, a questionnaire to evaluate the proposed Workbook was distributed to students, teachers and experts.

The results from the analysis of the questionnaire served as the basis to revise and improve the proposed Workbook.

2) Documentary Analysis

A documentary analysis was conducted to achieve a contextual understanding of the policy and practice environment of college English teaching. Relevant documents were obtained and analyzed. The relevant documents included instructional materials, policy statements, standards, as well as reports related to English Teaching and Learning for college students from regional, provincial and national government offices.

3) Interview

Interviews with a number of respondents and college English teachers were conducted through the research to obtain appropriate data in formulating and evaluating the Workbook. The items reflected in the questionnaire were used as interview guide. These interviews were made specifically for the collation of the collected data, particularly in the process of analysis and interpretation.

\subsection{Research Procedure}

The following were the steps used in conducting this study:

1) Surveying the existing instructional materials;

2) Planning the Workbook;

3) Modifying the Workbook; and

4) Preparing the Final Draft of the Workbook.

\section{Overview of the Existing Instructional Materials in Speaking}

A survey was conducted to evaluate the existing instructional materials in 
speaking used in TKKC. They were evaluated by college English teachers in terms of adequacy, authenticity, language, content, and activities through a survey questionnaire which was culled and adopted from theories of Task-Based Language Teaching (Nunan, 2004), and the study by Tolentino (2008).

The collected data in Table 1 indicate that the respondents disagree to the adequacy of the available instructional materials and there is still a need for the production of instructional materials in speaking for first year college EFL students. In terms of authenticity, the data show that the availability of authentic materials in speaking is limited. Besides, the language used in the existing instructional materials is still not easy for the target learners to grasp. Thus, there is still a need to simplify the language used in the instructional materials. In addition, the data show that the contents of the existing instructional materials in speaking are not in accordance with the abilities of the target learners, because most of the materials being used contain too much abstract information which is intended for students with higher English proficiency level. What's more, the respondents were not convinced that there are adequate workable activities in speaking for first year college EFL students. Thus, more workable activities suited to this type of students are to be addressed.

Table 1. Average mean and sub-area mean of the evaluation on existing instructional materials in speaking for $1^{\text {st }}$ year college EFL students.

\begin{tabular}{ccc}
\hline Item No. & M & Interpretation \\
\hline Adequacy & 2.6 & MA \\
1 & 2.4 & DS \\
2 & 2.5 & F \\
Sub-Area Mean & & \\
Authenticity & 2.8 & MA \\
3 & 2.8 & S \\
Sub-Area Mean & & \\
Language & 2.7 & MA \\
4 & 2.9 & MA \\
5 & 2.8 & S \\
Sub-Area Mean & & \\
Content & 2.4 & DS \\
6 & 2.6 & MA \\
7 & 2.5 & F \\
Sub-Area Mean & & F \\
Activities & 2.135 & DS \\
8 & 2.6 & MA \\
9 & 2.55 & \\
Sub-Area Mean & & \\
General Average & & \\
\hline
\end{tabular}

Legend: SA-Strongly Agree, E-Excellent, A-Agree, VS-Very Satisfactory, MA-Moderately Agree, S-Satisfactory, D-Disagree, F-Fair, SD-Strongly Disagree, NI-Needs Improvement. 


\section{Production of the Proposed Task-Based Workbook}

\subsection{The Content of the Proposed Workbook}

Identifying the contents included in the Workbook was done through the collected data taken from the interviews and the results of the questionnaires. The contents came from a wide range of sources, and were as authentic as possible. Based on the survey and the researcher's study, the first version of the Workbook was drafted.

The Workbook comprises topics regarding $21^{\text {st }}$ century issues, such as global warming, population, health, Apple products, which are close to students' lives as well. It enables learners to connect the contents to their own real lives. Therefore, the proposed workbook is composed of eight (8) topics: Back to School, My Family, Healthy Diet, Birthday Party, A Trip to Hong Kong, Online Shopping, I-Time and Global Warming.

\subsection{The Organization of the Proposed Workbook}

In the organization of the proposed Task-Based Workbook, the researcher had analyzed different instructional books. The researcher also looked into activity books and workbooks in China and abroad, various ESL/EFL games, and activities from the Internet as the basis in developing the Workbook. She also took note of the suggestions of the experts in the field of English education. The proposed Workbook, however, is different in its treatment of the topics, tasks and illustrations. The proposed Workbook is presented in eight (8) lessons. Included in each lesson are the following:

\section{1) Objectives}

There are two kinds of objectives incorporated in the Workbook, namely: general and specific objectives. In accordance with the guidelines for English instruction to non-English major students set by the Chinese Ministry of Education as expressed in the College English Curriculum Requirements, the researcher adopted the following general objectives for teaching speaking to first year college EFL students in TKKC:

- Enable students to communicate in English in the course of learning.

- Enable students to conduct discussions on a given theme, and to talk about everyday topics in English.

- Enable students to give, after some preparation, short talks on familiar topics with clear articulation and basically correct pronunciation and intonation.

- Equip students with basic conversational strategies in dialogue.

- Develop students' critical thinking skills (analytical, synthetic, critical).

- Develop intercultural understanding and appreciation.

- Promote students' positive attitudes toward the target language and culture.

- Enhance students' abilities to work with others.

The general objectives direct the faculty members on what they should aim to achieve in each lesson or the course as a whole. The specific objectives, on the other hand, describe what the students are expected to be able to do as a result of 
their involvement in their learning opportunities in each lesson. The specific objectives are relevant to the tasks of each lesson and make use of simple and behavioral terms which are obvious to the students.

\section{2) Warming up}

Important words or sentence structures which are focused on in each lesson are presented in the warming up section. It is filled with relevant images, guessing games, word hunt games or giving opinions which will maintain students' interest and remind them of what they already know of the subject of the lesson.

\section{3) Language focus}

The language focus section presents the sentence structures which are made use of in the discussion, description, presentation, debating and some other activities while completing the tasks.

\section{4) Listen and answer}

A speaker is having real difficulties in appreciating what a particular task requires in simple practice in tasks. Nunan (1999) argues that giving speakers experience in the hearer's role is more helpful. Brown and her colleagues (cited in Nunan, 1999) found that prior experience as a listener helps speakers improve their performance as a speaker. The listen and answer section gives students models to deploy when they carry out the succeeding tasks. Being a hearer first, in addition, helps students appreciate the difficulties inherent in the task.

\section{5) Tasks}

The tasks presented in each part are sequenced. The first task fulfills a similar function as schema-building tasks in larger instruction sequences. It orients the students to the task, generates interest, and rehearses essential language that will be required to complete the task. The succeeding task is the main task students are mainly required to complete. In the follow-up task they get a debriefing from the teacher, report the results of the task back to the class as a whole, and may receive corrective feedback from the teacher.

\section{6) Pronunciation}

The pronunciation section presents the common mistakes in English pronunciation made by students with Chinese Language background. In this section, students are required to listen, practice and give more examples of common mistakes. Syllables, stress, ending consonant, short and long vowels, voiced and unvoiced "th" sounds are given focus.

\section{7) Self-Assessment}

In order to check whether specific objectives have been achieved by the students or not, self-assessment is presented after each lesson.

In addition to assessment by the teacher, self- and peer assessments are also becoming popular (Nunan, 2004). Students are encouraged to manage their own study autonomously and give focus on the learning processes as well as learning outcomes.

\subsection{Evaluation and the Final Draft of the Proposed Workbook}

Careful and critical examination of the tasks and procedure in the Workbook 
determined the extent to which the Workbook represented the objectives considered in its preparation. Sixty (60) EFL students, ten (10) college English teachers and three (3) English experts were requested to evaluate the proposed Workbook through a questionnaire which was prepared based on literatures (Cohen et al., 2004; Hall, 2001; Nunan, 2004), and studies (Angeles, 2009; Manalang, 2008; Sanchez, 2006; Tolentino, 2008) in terms of objectives, content, readability, procedure, assessment and lay-out.

Table 2 presents the average of the sub-area means of the evaluation of the students, teachers and experts on the different areas of the proposed Workbook. It can thus be summed up that the average responses of the respondents are excellent in all areas, namely: objectives, content, readability, procedure, assessment and lay-out although it can be observed from the table that the experts gave a consistently higher evaluation than the students and teachers did. According to the results of the evaluation by students, teachers and experts, the Workbook was modified and improved. Finalized Workbook for Developing English Language Speaking Skills of First Year College EFL Students in China was the output of the study.

Table 2. Summary of the sub-area means of the evaluation by the respondents of the different areas of the proposed workbook.

\begin{tabular}{ccccc}
\hline AREA & $\begin{array}{c}\text { SUB-AREA } \\
\text { MEAN } \\
\text { (Students) }\end{array}$ & $\begin{array}{c}\text { SUB-AREA } \\
\text { MEAN } \\
\text { (Teachers) }\end{array}$ & $\begin{array}{c}\text { SUB-AREA } \\
\text { MEAN } \\
\text { (Experts) }\end{array}$ & Average/Interpretation \\
\hline Objectives & 4.35 & 4.24 & 4.80 & $4.46(\mathrm{E})$ \\
Content & 4.34 & 4.28 & 4.80 & $4.47(\mathrm{E})$ \\
Readability & 4.24 & 4.35 & 4.53 & $4.37(\mathrm{E})$ \\
Procedure & 4.29 & 4.29 & 4.50 & $4.36(\mathrm{E})$ \\
Assessment & 4.28 & 4.22 & 4.67 & $4.39(\mathrm{E})$ \\
Lay-out & 4.44 & 4.37 & 4.58 & $4.46(\mathrm{E})$ \\
\hline
\end{tabular}

\section{Conclusion and Recommendations}

It was revealed in the study that there were not enough instructional materials in speaking for the first year EFL students in TKKC. In general, the content of the existing instructional material in speaking was really intended for higher-English-proficient students and did not meet the students' needs and not appropriate for the target students. Therefore, the study's aim was to produce a task-based workbook to help first year college EFL students to improve speaking skills. The proposed task-based workbook will be beneficial and contributory to attaining confidence in speaking, and preparing the said students to tackle more difficult speaking skills, like fluency, accuracy, etc.

While the proposed Workbook in speaking is being validated, teachers should take note of the entry levels of the target users. Comments/suggestions and/or necessary revisions for its future modifications are needed. Graduate students 
pursuing English education and EFL/ESL teachers should be encouraged to produce similar workbooks on other levels to facilitate instruction and learning of speaking skills. Most importantly, school officials should offer their support to teachers who find ways to improve students' learning in their effort to augment the needed materials in the teaching of speaking.

\section{Conflicts of Interest}

The author declares no conflicts of interest regarding the publication of this paper.

\section{References}

Angeles, L. D. (2009). A Proposed Instructional Guide in Developing Fine Motor Skills of Children with Down Syndrome. An Unpublished Master's Thesis, Angeles, Pampanga: Angeles University Foundation.

Cohen, L., Manion, L., \& Morrison, K. (2004). A Guide to Teaching Practice. New York: Routledge Falmer.

Cook, V. (2008). Second Language Learning and Language Teaching. London, UK: Hodder Education.

Hall, J. K. (2001). Methods for Teaching Foreign Language: Creating a Community of Learners in the Classroom. Hoboken, NJ: Prentice-Hall, Inc.

Huang, J. L. (2006). The Excessiveness and Insufficiency of the College English Education. Journal of Shangrao Normal College, 26, 109-116.

Kothari, C. R. (2008). Research Methodology: Methods and Techniques. New Age International.

Manalang, B. P. (2008). A Proposed Self-Help Task-Oriented Activities Book in Teaching Children with Mental Retardation. An Unpublished Master's Thesis, Angeles, Pampanga: Angeles University Foundation.

Nunan, D. (1999). Second Language Teaching and Learning. Boston, MA: Heinle and Heinle Publishers.

Nunan, D. (2004). Task-Based Language Teaching. New York: Cambridge University Press.

Richards, J. C., \& Rodgers, T. S. (2001). Approaches and Methods in Language Teaching. Cambridge, UK: Cambridge University Press. https://doi.org/10.1017/CBO9780511667305

Sanchez, M. L. B. (2006). A Proposed Enrichment Book in Reading for Learners with Mild Mental Retardation. An Unpublished Master's Thesis, Angeles, Pampanga: Angeles University Foundation.

The National Foreign Language Teaching Advisory Board (2020). College English Curriculum Requirements. Beijing: High Education Press.

Tolentino, M. P. (2008). Proposed Task-Based Reading Activities in Teaching Children with Learning Disabilities. An Unpublished Master's Thesis, Angeles, Pampanga: Angeles University Foundation. 